\title{
Enhancing Regular Monitoring of Food-Contact Surface Hygiene with Rapid Microbial Kits
}

\author{
Mazni Saad'1 , Toh Poh See², \\ Mohd Faiz Foong Abdullah ${ }^{3}$, Norazmir Md. Nor ${ }^{4}$
}

1 Faculty of Business, Universiti Selangor, 40000 Shah Alam, Selangor, Malaysia

2 Faculty of Hotel and Tourism Management, Universiti Teknologi MARA, 42300 Puncak Alam, Selangor, Malaysia

${ }^{3}$ Faculty of Applied Sciences, Universiti Teknologi MARA, 40450 Shah Alam, Selangor, Malaysia

${ }^{4}$ Faculty of Health Sciences, Universiti Teknologi MARA, 42300 Puncak Alam, Selangor, Malaysia

maznisaad@unisel.edu.my

\begin{abstract}
To ensure that food is always healthy and safe, food business operators utilize a simple and practical method of identifying and verifying microbes. This study looks at the practicality of an inexpensive and user-friendly microbial kit that evaluates the cleanliness level of 72 samples of food-contact surfaces (FCS) of food service establishments in two states of Malaysia. It detected $70 \%$ coliform contamination which suggests that food service operators may need to improve the cleanliness of FCS. It can be concluded that the microbial kit used is a practical self-check approach for determining the hygiene level of any food service operation and should be made mandatory.
\end{abstract}

Keywords: Food safety; food-hygiene practices; microbial kits; food handlers

eISSN 2398-4295 @ 2018. The Authors. Published for AMER ABRA cE-Bs by e-International Publishing House, Ltd., UK. This is an open-access article under the CC BY-NC-ND license (http://creativecommons.org/licenses/bync-nd/4.0/). Peer-review under responsibility of AMER (Association of Malaysian Environment-Behaviour Researchers), ABRA (Association of Behavioural Researchers on Asians) and CE-Bs (Centre for EnvironmentBehaviour Studies), Faculty of Architecture, Planning \& Surveying, Universiti Teknologi MARA, Malaysia.

http://dx.doi.org/10.21834/ajbes.v3i11.103 


\subsection{Introduction}

Cooking food obliterates harmful microorganisms and makes it safe for consumption. However, adding garnishes, cutting or slicing cooked food can potentially reintroduce harmful organisms into it. Such activities must be done with clean hands and utensils such as foodcontact surfaces (FCS) as the final product is no longer subjected to any heating. Failure to observe self-hygiene practices related to FCS and the environment could lead to food spoilage and the spread of illnesses like food poisoning.

In Malaysia, from 2000 to 2012 besides cholera, hepatitis A, typhoid, and dysentery, food poisoning was the most critical foodborne illness recorded (Mazni, Toh, \& Mohamed Azam, 2013). Short term symptoms of food poisoning like upset stomach, abdominal cramps, nausea, vomiting, diarrhoea, fever, and dehydration are not devastating compared to longterm effects associated with kidney failure, chronic arthritis, brain and nerve damage or death (U.S. Department of Health \& Human Services, 2013). There are other infectious foodborne outbreaks closely related with bacteria, viruses, parasites, mold, toxins, contaminants and allergens include Caliciviruses (norovirus), Salmonella spp., Hepatitis A, Shigella spp., Staphylococcus aureus, Streptococcus pyogenes, Salmonella typhi/parathyphi, Vibrio cholera 01, Yersiniasenterocolitica, Giardia lamblia, Campylobacter jejuni, Cryptosporidium parvum, Escherichia coli 0157:H7, Cyclosporacayetanensis, and Entamoebahistolytica (Michaels et al., 2004).

Food service hygiene is enforced in compliance with the 1983 Food Act and the 2009 Food Hygiene Regulations (Mazni et al., 2013). Inspection of the cleanliness of food premises and handlers by the Ministry of Health involve laboratory investigation and result only in food seizures and legal action on the organization and do not benefit food handlers. This study, therefore, measures the practicability of hygiene practices of critical food services in two Malaysian states by evaluating the cleanliness of FCS using a rapid microbial kit.

\subsection{Literature Review}

\section{Food safety}

Food safety is indispensable to human life. Ensuring safe and hazard-free food from farm to fork is challenging (Menkovska, 2011; Payne-Palacio \& Theis, 2012). The adverse consequences and associated probabilities arising from contaminated foods with microbial pathogens must, therefore, be identified, assessed and systematically controlled (Lammerding \& Fazil, 2000).

However, food safety is difficult to define and measure and requires proper and continuous efforts by competent authorities, business operators, scientists, consumers, and sector representatives (Belgian Federal Agency for the Safety of the Food Chain, 2010). Measures proposed globally include the implementation of standards and guidelines such as ISO 22000, Hazard Analysis Critical Control Point (HACCP) scheme, Good Manufacturing or Management Practices (GMP) scheme (Arvanitoyannis \& Varzakas, 2009). A scientific basis for managing risks related to food consumption such as Food Safety Barometer 
developed by the Scientific Committee of the Belgian Food Safety (Havelaar, Nauta, \& Jansen, 2004).

\section{Food-contact surface}

Garnishing, chopping, deboning, and slicing usually take place on FCS and so measuring transmission of foodborne pathogens in ready-to-eat (RTE) food in FCS is a priority (Cosby et al., 2008). A contaminated FCS is more critical to human health than contaminated food. FCS such as cups, plates, cutting boards, and food preparation table can be re-contaminated after routine cleaning and will spoil RTE food that comes in direct contact with it since such food does not go through any more heating. The strong relationship between FCS and food safety risks is proven when Rodriguez et al. (2011) found high bacteria counts on cutting boards and kitchen faucets of long-term care facilities in Andalusia. Cunningham et al. (2011) found the highest average counts of bacteria on slicers and cutting boards of retail food establishments in Minneapolis.

\section{E.coli and Coliform}

Coliforms in general and Escherichia coli (E.coli) in particular are traditional indicators of faecal contamination in water and other environmental samples (Enoch et al., 2013; Martinon, Cronin, Quealy, Stapleton, \& Wilkinson, 2012). E.coli is true faecal bacteria (Atlas et al., 1994; Nkere, Ibe, \& Iroegbu, 2011) while coliforms signify the most common contamination in faecal wastes (Dorothy \& Philip, 1998; Willis, Elviss, Aird, Fenelon, \& Mclauchlin, 2012).

\section{Practical Identification of Pathogenic Bacteria}

To diagnose and treat infectious diseases, microorganisms have to be rapidly and reliably identified. Traditionally, this is done by isolating pathogenic bacteria from clinical samples and propagating it on a culture medium in a routine laboratory (Trotha, Konig, \& Konig, 2001). However, this is costly and laborious and is not specific (Wilson et al., 1991) in detecting true faecal coliforms such as E.coli, for example.

The on-site and in-field detection method is recommended for foodborne outbreaks caused by contaminated fresh produce like lettuce and cantaloupes (Park \& Oh, 2012). Park et al. (2013) found that almost all surface areas of fresh produce have uniform bacterial cells and introduced detection of $S$. Typhimurium on-site and in real-time with minimum sample preparation. This method is cheap and practical and is effective in improving the safety of fresh fruits and vegetables. The same detection method is recommended when an outbreak occurs along the food chain (Beuchat and Ryu, 1997). This study, therefore, demonstrates the rapid use of RIDA ${ }^{\circledR}$ COUNT test plate to regularly monitor food handling practices involving FCS. 


\subsection{Methodology}

\section{Collection of samples}

Sampling was done during the actual food service operation of six providers. There was a total of 72 FCS samples in four different categories of the dining table, food tray, cooking pot and kitchen faucet. These utensils had been routinely rinsed. The RIDA ${ }^{\circledR}$ COUNT test plate estimated the total bacterial count of E.coli and coliforms found on FCS (Fig. 1. (a) and (b)).

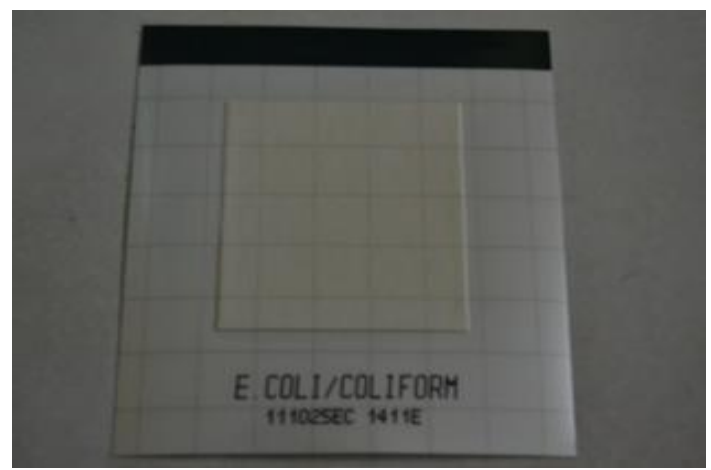

Figure 1a: $\operatorname{RIDA}^{\circledR}$ count plate

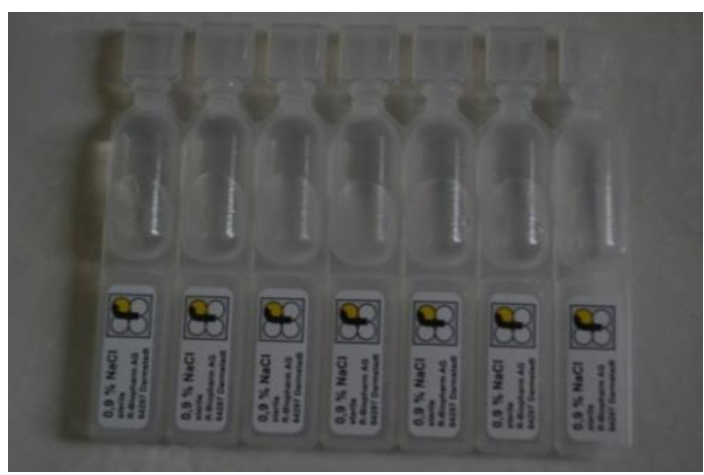

Figure 1b: Natrium Chloride solution

\section{Sampling procedure}

E.coli and coliforms were accessed via RIDA Count ${ }^{\circledR}$ and Colilert Test. Swabbing began with labelling and coding the $\operatorname{RIDA}^{\circledR}$ count plates according to sample type, date, a number of duplicates, and a name of food service. Subsequently, the dry-ready-agar was soaked in one millilitre of Natrium Chloride solution on RIDA ${ }^{\circledR}$ count plates for 15 minutes (Fig. 2). Slight pressure was applied five times inside the designated $10 \mathrm{~cm} \times 10 \mathrm{~cm}$ FCS sampling area; 
north-east and north-west, south-west and south-east and in the middle of these four positions. Finally, all the RIDA ${ }^{\circledR}$ count plates were put in sterile plastic bags and stored in a cool box at a temperature of between $0^{\circ}$ and $4^{\circ} \mathrm{C}$.

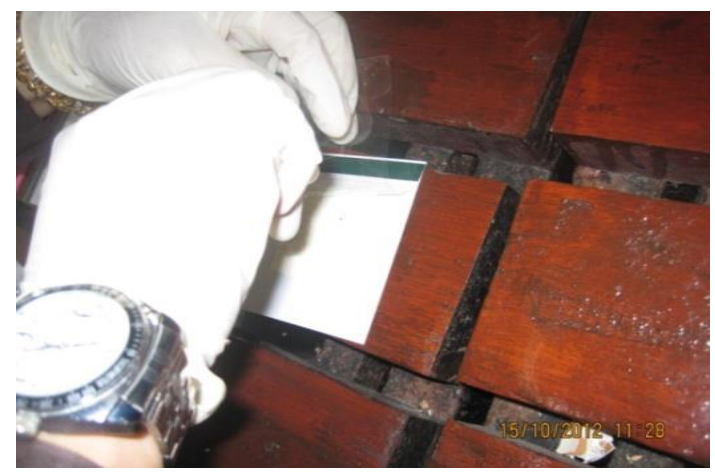

Figure 2: Swabbing preparation process in Food Service 1, Selangor. (Source: Author's personal photo collection)

\subsection{Results and Discussions}

Tests were conducted to determine the cleanliness of FCS after regular cleaning. Colonies were observed, with purple to indigo indicating E.coli and light blue signifying total coliforms. The microbial colonies in the colony-forming units (CFU) per $10 \mathrm{~cm} \times 10 \mathrm{~cm}$ surface (100 $\mathrm{cm}^{2}$ ) were counted and transformed to log10 by using SPSS version 21.0 .

\section{Prevalence of E.coli and Coliforms: a Microbial Analysis}

Table 1: Critical microbial counts for E.coli and coliform on sampled food-contact surfaces Counts $\left(\log _{10} \mathrm{CFU} / \mathrm{cm}^{2}\right)$

\begin{tabular}{|c|c|c|c|c|c|c|c|c|c|c|c|c|}
\hline \multirow{2}{*}{$\begin{array}{l}\text { Sample } \\
\text { Area }\end{array}$} & \multicolumn{2}{|c|}{$\begin{array}{c}\text { FoodService } \\
1\end{array}$} & \multicolumn{2}{|c|}{$\begin{array}{c}\text { FoodService } \\
2\end{array}$} & \multicolumn{2}{|c|}{$\begin{array}{c}\text { FoodService } \\
3\end{array}$} & \multicolumn{2}{|c|}{$\begin{array}{c}\text { FoodService } \\
4\end{array}$} & \multicolumn{2}{|c|}{$\begin{array}{c}\text { FoodService } \\
5\end{array}$} & \multicolumn{2}{|c|}{$\begin{array}{c}\text { FoodService } \\
6 \\
\text { EC TC }\end{array}$} \\
\hline & & & & & & & & & & & & \\
\hline $\begin{array}{l}\text { Dining } \\
\text { table tops }\end{array}$ & - & ++ & - & ++ & - & + & - & ++ & - & ++ & - & ${ }^{++}$ \\
\hline $\begin{array}{l}\text { Food } \\
\text { trays }\end{array}$ & - & ++ & - & ++ & - & + & - & ++ & - & ${ }^{++}$ & - & - \\
\hline $\begin{array}{l}\text { Cooking } \\
\text { pots }\end{array}$ & - & - & - & + & - & - & - & ++ & - & ++ & + & ++ \\
\hline $\begin{array}{l}\text { Kitchen } \\
\text { faucets }\end{array}$ & - & - & - & - & - & ++ & - & + & - & - & - & - \\
\hline
\end{tabular}

Note. - non detection for E. coli (EC), Total Coliforms (TC); + TC $<1.0 \log _{10} \mathrm{CFU} / \mathrm{cm}^{2} ;++\mathrm{TC} \geq 1.0 \log _{10}$ $\mathrm{CFU} / \mathrm{cm}^{2}$ 
Table 1 shows a 70\% coliform contamination of all FCS, with $54 \%$ highly affected. These FCS were, therefore, unsuitable for food preparation. However, except for cooking pots in Food Service 6, they did not contain E.coli. Table 1 also reflects widespread use of unhygienic FCS, implying that washing and sanitation practices have not been effectively implemented for almost all sampled FCS.

Fig. 3 illustrates less than desirable hygiene level of FCS; $58 \%$ faecal contamination of dining table tops, $33 \%$ of food trays, $33 \%$ of cooking pots and $8 \%$ of kitchen faucets. It indicates that all six foodservice operations need to improve the cleanliness of FCS and undergo general periodic inspection of hygiene levels.

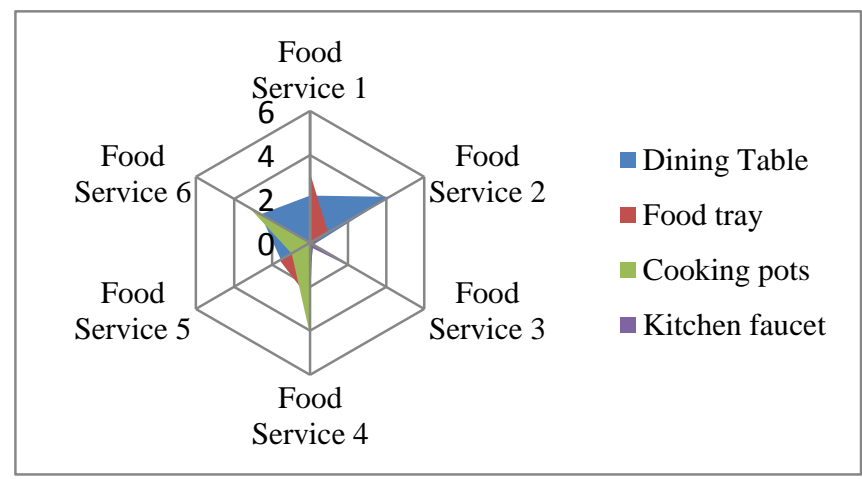

Figure 3: Microbial counts for coliforms are shown in $\log _{10} \mathrm{CFU} / \mathrm{cm}^{2}$.

(Source: Author's personal photo collection)

\section{Implications of the findings}

Unhygienic FCS pose risks on food. Therefore, regular monitoring of FCS is critical as it is a food preparation medium. It must also include finding critical points in the operation that negatively affect food quality (Salo et al., 2006 \& Mulec et al., 2012). Food handlers too need to self-check regularly to take immediate remedial action. As such the tedious traditional testing method should make way for a user-friendly microbial kit to enhance monitoring. Food handlers' increased participation in best practices will create much curiosity and a change in attitude towards better compliance to food safety guidelines (Faizi, Azaria, \& Maleki, 2013).

This study could contribute to improvements in Food Act and Regulations in Malaysia. The 1983 Food Act specifies food and water standards for coliform and E.coli but does not account for solid materials like FCS. Also, RIDA ${ }^{\circledR}$ count plates (R-Biopharm AG, Germany) is a rapid indicator kit issued in Germany, thus replicating and producing it locally would save cost.

The Ministry of Health and the Municipality will also have access to important information on effective strategies and preventive measures in handling hygiene issues. A triangulation of these hygiene measures and practices could prove crucial in assuring that food is safely prepared at all times (Mazni et al., 2013). 


\section{Limitation and recommendation for future research}

There are shortcomings in the data collection method used by field researchers of this study as they were not immunised and were barred from entering the kitchen. Swab activities were done only on kitchen equipment in the dining hall and excluded heavy-duty equipment such as tilting fry-pans, steam-jacketed kettles, steamers, and reach-in refrigerators. It is recommended that future studies look at such equipment as they are very tough to clean and would potentially contain higher amounts of food residue. There is also need to consider training related to effective cleaning and sanitizing methods. Future research could finally consider looking for a shorter investigation period of such outbreaks.

\subsection{Conclusion}

Poor hygiene practices could provide some explanation for the persistent occurrence of foodborne outbreaks in Malaysia. This study recommends the regular use of rapid microbial test kits to detect the cleanliness level of hygiene practices of food service operations, thus promoting food safety in accordance with the requirements of the 1983 Food Act and the 2009 Food Hygiene Regulations. The RIDA® COUNT test plate is easy to use and interpret, allowing for weaknesses in hygiene practices to be swiftly pinpointed so that immediate correction steps can be taken. This regular monitoring could be done by the food handlers themselves and would automatically prompt a change in their attitude and behaviour towards ensuring better compliance with food safety guidelines. It is also viable that the use of the scientific kit be commercialized as a multi-purpose test-kit.

\section{Acknowledgement}

The Ministry of Health Malaysia through the Faculty of Hotel and Tourism Management, Universiti Teknologi MARA (RMI-P3018) has funded for this research.

\section{REFERENCES}

Arvanitoyannis, I. S., \& Varzakas, T. H. (2009). Application of ISO 22000 and comparison with HACCP on industrial processing of common octopus (Octopus vulgaris) - Part 1. International Journal of Food Science and Technology, $44,58-78$.

Atlas, R. M., Bej, A. K., Mahbubani, M. H., all of Louisville, K., Richard Miller, P., Ind., Steffan, R. J., Dak, N. (1994). 5,298,392. United States Patent.

Belgian Federal Agency for the Safety of the Food Chain. (2010). Measuring food safety and comparing self checking systems, from http://www.favv-afsca.be/selfcheckingsystems/

Beuchat, L. R. (2002). Ecological factors influencing survival and growth of human pathogens on raw fruits and vegetables. Microbes and Infection, 4, 413-423. 
Beuchat, L. R., \& Ryu, J. H. (1997). Produce handling and processing practices. Emerging Infectious Disease, 3 , 439-465.

Casey, C., \& Alach, P. (2004). 'Just a temp?' Women, temporary employment and lifestyle. Work, employment and society, 18(3), 459-480.

Cosby, C. M., Costello, C. A., Morris, W. C., Haughton, B., Devereaux, M. J., Harte, F., \& Davidson, P. M. (2008). Microbiological analysis of food contact surfaces in child care centers. Applied and Environmental Microbiology, 74(22), 6918-6922.

Cunningham, A. E., Rajagopal, R., Lauer, J., \& Allwood, P. (2011). Assessment of hygienic quality of surfaces in retail food service establishments based on microbial counts and real-time detection of ATP. Journal of Food Protection, 74(4), 686-690.

Dorothy, A. G., \& Philip, R. A. (1998). Technology of Bottled Water. USA: Sheffield Academic Press.

Enoch, D. A., Mlangeni, D. A., Ekundayo, J., Aliyu, M., Sismey, A. W., Aliyu, S. H., \& karas, A. (2013). Gram negative bacteraemia-are they preventable and what will E.coli surveillance add? Journal of Infection Prevention, 14(2), 5559 .

Havelaar, A. H., Nauta, M. J., \& Jansen, J. T. (2004). Fine-tuning Food Safety Objectives and risk assessment. International Journal of Food Microbiology, 93(1), 11-29. doi: http://dx.doi.org/10.1016/j.ijfoodmicro.2003.09.012

Lammerding, A. M., \& Fazil, A. (2000). Hazard identification and exposure assessment for microbial food safety risk assessment. International Journal Food Microbiology, 58(3), 147-157.

Martinon, A., Cronin, U. P., Quealy, J., Stapleton, A., \& Wilkinson, M. G. (2012). Swab sample preparation and viable real-time PCR methodologies for the recovery of Escherichia coli, Staphylococcus aureus or Listeria monocytogenes from artificially contaminated food processing surfaces. Food Control, 24, 86-94.

Mazni, S., Toh, P. S., \& Mohamed Azam, M. A. (2013, 18-21 March). Food handler's hygiene practices among government institutional training center in Northern region. Paper presented at the ASEAN Conference on Environment-Behaviour Studies (AcE-Bs2013Hanoi), Hanoi Architectural University, Vietnam.

Menkovska, M. (2011). Regulations and organs in the field of food and feed safety in republic of Macedonia. Macedonian Journal of Animal Science, 1(2), 355-360.

Michaels, B., Keller, C., Blevins, M., Paoli, G., Ruthman, T., Todd, E., \& Griffith, C. J. (2004). Prevention of food worker transmission of foodborne pathogens: risk assessment and evaluation of effective hygiene intervention strategies. Food Service Technology, 4, 31-49.

Mulec, J., Kristufek, V., \& Chronakova, A. (2012). Comparative microbial sampling from eutrophic caves in Slovenia and Slovakia using RIDA COUNT test kits. International Journal of Speleology, $41(1), 8$.

Nkere, C. K., Ibe, N. I., \& Iroegbu, C. U. (2011). Bacteriological quality of foods and water sold by vendors and in restaurants in Nsukka, Enugu State, Nigeria: A comparative study of three microbiological methods. Journal of Health, Population, \& Nutrition, 29(6), 560-566.

Park, M.-K., \& Oh, J.-H. (2012). Rapid detection of Escherichia coli 0157:H7 on turnip greens using a modified gold biosensor combined with light microscopic. Journal of Food Science, 77(2), 127-134. 
Park, M.-K., Weerakoon, K. A., Oh, J.-H., \& Chin, B. A. (2013). The analytical comparison of phage-based magnetoelastic biosensor with TaqMan-based quantitative PCR method to detect Salmonella Typhimurium on cantolaoupes. Food Control, 33, 330-336.

Payne-Palacio, J., \& Theis, M. (2012). Foodservice Management Principles and Practices (12th. Ed. ed.): Prentice Hall.

Rodriguez, M., Valero, A., Posada-Izquierdo, G. D., Carrasco, E., \& Zurera, G. (2011). Evaluation of food handler practices and mirobiological status of ready-to-eat foods in long-term care faciliteis in Andalusia region of Spain. Journal of Food Protection, 74(9), 1504-1512.

Salo, S., Ehavald, H., Raaska, L., Vokk, R., \& Wirtanen, G. (2006). Microbial surveys in Estonian dairies. LWT, 39, 460-471.

Trotha, R., Konig, T. H. W., \& Konig, B. (2001). Rapid ribosequencing - an effective diagnostic tool for detecting microbial infection. Infection, 29, 12-16.

U.S. Department of Health \& Human Services. (2013, 28 April 2013). FoodSafety.gov: Your Gateway to Federal Food Safety Information Retrieved 28 April, 2013, from www.foodsafety.gov/poisoning/effects/index.html

Willis, C., Elviss, N., Aird, H., Fenelon, D., \& Mclauchlin, J. (2012). Evaluation of hygiene practices in catering premises at large-scale events in the UK: Identifying risks for the Olympics 2012. Public Health, 126, 646-656.

Wilson, K., Blitchington, R., Frothingham, R., \& Wilson, J. (1991). Phylogeny of the Whipple's-disease-associated bacterium. Lancet, 338, 474-475. 